\title{
The geotouristic attractiveness of the underground trails in Zabrze, Dąbrowa Górnicza and Tarnowskie Góry towns (Silesian Upland)
}

\author{
Atrakcyjność geoturystyczna tras podziemnych \\ w Zabrzu, Dąbrowie Górniczej i Tarnowskich Górach (Wyżyna Śląska)
}

\section{Maciej Dzięgiel}

AGH University of Science and Technology, School of Environmental Protection and Engineering, al. Mickiewicza 30, Krakow, Poland md248@wp.pl
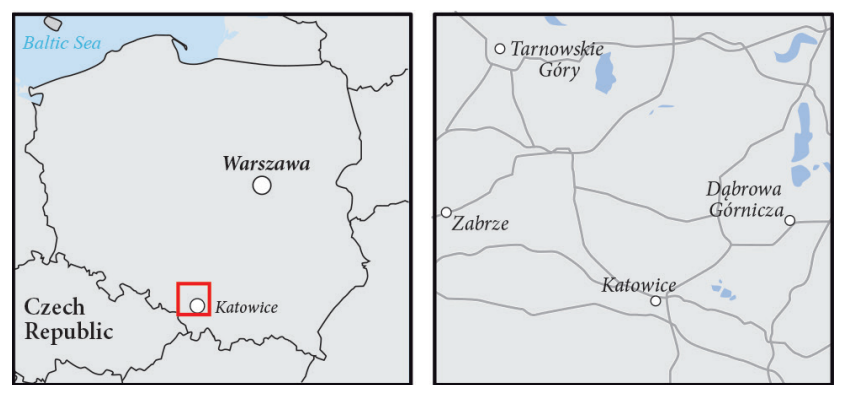

\author{
Article history: \\ Received: 26 January 2021 \\ Accepted: 20 July 2021 \\ Available online: 2021
}

(C) 2020 Authors. This is an open access publication, which can be used, distributed and reproduced in any medium according to the Creative Commons CC-BY 4.0 License requiring that the original work has been properly cited.

\begin{abstract}
In Zabrze, Dąbrowa Górnicza and Tarnowskie Góry towns, seven underground tourist trails are located in historical mines. Four of them were developed in the central part of the Upper Silesian Coal Basin, two of which, at the "Królowa Luiza" ("Queen Louise") Adit (comprising the former coal mine "Królowa Luiza" and the drainage Main Key Hereditary Adit remnant), and two others at the "Guido" Mine in Zabrze town. The next one was developed in the eastern part of the Upper Silesian Coal Basin, in a part of the "Sztygarka" Training Coal Mine in Dąbrowa Górnicza. Two other trails are located in Tarnowskie Góry town, in the border zone between the Upper Silesian Coal Basin and the Silesian-Kraków Monocline. These are the relics of the historical lead, zinc and silver ore mine, and the "Czarny Pstrag" ("Black Trout") drainage adit. The bituminous coal deposits are hosted in the Upper Carboniferous clastic formations, which fills the Upper Silesian Coal Basin. The metal ores are hosted in Middle Triassic dolomites, which belong to the southern margin of the Silesian-Kraków Monocline. The geotourism attractiveness of all these historical mines was demonstrated by selected annual statistical data of tourist attendance. In general, the interest in these facilities has been growing since decades, same as the popularity of industrial heritage in the Upper Silesia. These three towns have become very widely known in Poland and in the world.
\end{abstract}

Keywords: Upper Silesian Coal Basin, Silesian-Kraków Monocline, underground tourist trails, coal mine, zinc, lead and silver mine

Treść: W Zabrzu, Dąbrowie Górniczej i Tarnowskich Górach utworzono w sumie siedem podziemnych tras turystycznych prowadzonych wyrobiskami górniczymi zabytkowych kopaln. Cztery z nich znajduja się w Zabrzu, w centrum Górnośląkiego Zagtębia Węglowego, a jedna w Dąbrowie Górniczej, na jego wschodnim krańcu. Dwie pozostałe sa natomiast zlokalizowane na pograniczu Górnośląskiego Zagłębia Węglowego i Monokliny Śląsko-Krakowskiej, w Tarnowskich Górach. Na terenie Zabrza dwie podziemne trasy turystyczne zostały wytyczone w Sztolni „Królowa Luiza”, zespole tączacym wybrane wyrobiska dawnej kopalni węgla kamiennego „Królowa Luiza” z odwadniająca ją Gtówna Kluczową Sztolnia Dziedziczna, a pozostałe dwie w zabytkowej kopalni węgla kamiennego „, Guido”. W Dąbrowie Górniczej udostępniono do zwiedzania część wyrobisk górniczych dawnej Kopalni Ćwiczebnej ,,Sztygarka”, natomiast w Tarnowskich Górach podziemne trasy turystyczne wyznaczono w zabytkowej kopalni srebra i sztolni „, Czarnego Pstraga”. Ztoża węgla kamiennego występuja w klastycznych osadach górnokarbońskich Górnośląskiego Zagłębia Węlowego, natomiast rud metali - w środkowotriasowych dolomitach kruszconośnych południowej części obszaru Monokliny Śląsko-Krakowskiej. Atrakcyjność geoturystyczna poszczególnych tras podziemnych została określona na podstawie porównania wyników analiz statystycznych frekwencji turystów w poszczególnych obiektach. Generalnie obserwowany jest jej wzrost na przestrzeni lat, wraz ze zwiększająca się popularnościa dziedzictwa przemysłowego na Górnym Śląsku z biegiem czasu, zarówno w Polsce, jak i na catym świecie.

Słowa kluczowe: Górnośląskie Zagłębie Węglowe, Monoklina Śląsko-Krakowska, trasy podziemne, kopalnia węgla, kopalnia rud metali 


\section{Introduction}

The history of mining in the central part of the Silesian Upland (www1; Fig. 1) is very long. Two main types of mineral resources were exploited: bituminous ("hard") coal and zinc, lead and silver ores. The bituminous coal mining has started in Zabrze town (Fig. 1) in 1791 and has lasted until 1998. The "Królowa Luiza" ("Queen Louise") coal mine located in this town was the oldest one in the Silesian Upland (Dzięgiel, 2007; www1; Fig. 1). Bituimous coal was exploited in numerous locations, but most of these mines had to be closed in the 1990s because of exhaustion of reserves and environmental issues. In Dąbrowa Górnicza town (Fig. 1), coal had been mined in the years 1865-1995 (Ciepiela, 2007; Bielecki, 2008). Metal ores were extracted in Tarnowskie Góry town (Fig. 1), in the $16^{\text {th }}$ century and again, between the $18^{\text {th }}$ and $20^{\text {th }}$ centuries, and their production has ceased in 1922 (Dzięgiel, 2008).

Some parts of three former coal mines in the Silesian Upland have already been transformed into the museums. These are: "Królowa Luiza" Mine, available since 1993 as the "Mining Open-Air Museum" (Dzięgiel, 2007; Frużyński, 2012), the "Guido" Mine, accessible since 2007 (Dzięgiel, 2011; Frużyński, 2012; Piątek, 2013), both located in Zabrze town, and the "Sztygarka" Training Mine in Dąbrowa
Górnicza town, in operation since 2010 (Wójcik \& Chmura, 2008; Chmura \& Wójcik, 2009; www2). Since 2018, the selected old workings of the former "Królowa Luiza" Mine have been connected to the final section of the old drainage working named the "Main Key Hereditary Adit", and, therefore, it is currently called the "Królowa Luiza" Adit (Drobniak et al., 2020; Gola, 2020; www3). The "Królowa Luiza" Adit and the "Guido" Mine are also the branches of the Coal Mining Museum in Zabrze, established in 1981 (Gola, 2020).

Two small parts of the old metal ore mine in Tarnowskie Góry were also adapted as geotourism attractions: the Historical Silver Mine (opened in 1976) and the "Czarny Pstrąg" ("Black Trout") Adit, which has been accessible for public use since 1957 (Szlachcic-Dudzicz, 2006; Dzięgiel, 2008; Wyciszczak, 2008; Czornik et al., 2011; Pawlak \& Filak, 2017; www4).

In recent years, all these underground trails were included into the Silesian Industrial Monuments Route and the European Route of Industrial Heritage (Czornik et al., 2011; Drobniak et al., 2020; www5; www6). The Annual Fest of the Silesian Industrial Monuments Route, called "Industriada", jointly celebrated in all these sites, represents a great part of the Silesian Industrial Monuments promotion (www6). Hence, these trails have become very popular in Poland and in the world.

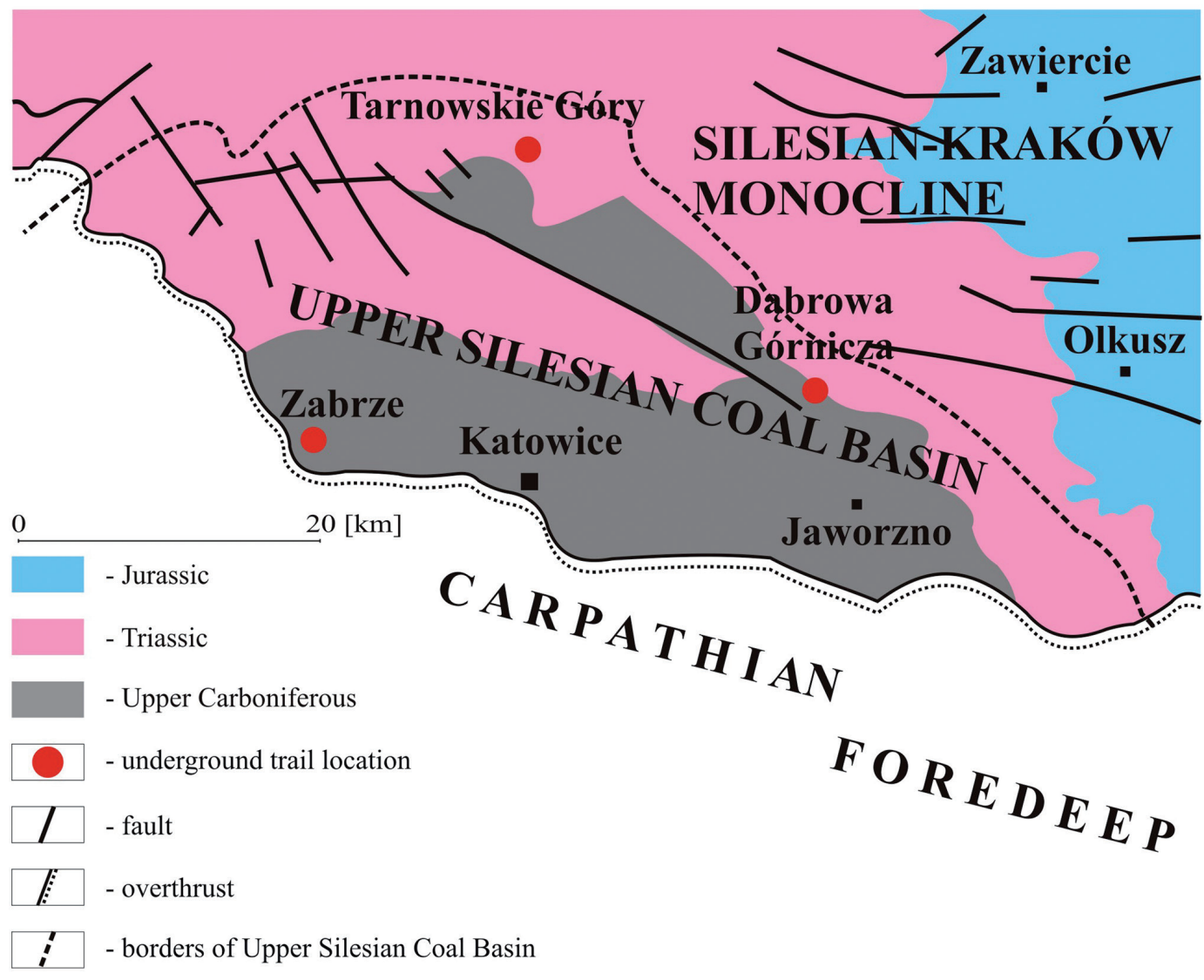

Fig. 1. Location of Zabrze, Dąbrowa Górnicza and Tarnowskie Góry towns in the Silesian Upland (after www1), referred to the Silesian-Kraków Monocline and to the Upper Silesian Coal Basin (after Bukowy et al., 1974) 
The aim of this article is to indicate the geotourism attractiveness of these objects. The criterion, chosen for the analysis, is the number of tourists visiting each of described attractions.

\section{Methodology}

The research was carried on using the direct field observations and the photographic documentation run personally by the author at the described sites. Apart from that, some papers and statistics from the Polish databank were reviewed for obtaining the statistical data of tourists visits at the described sites.

\section{Geographical and geological settings of the central part of the Silesian Upland}

The three towns: Zabrze, Dąbrowa Górnicza and Tarnowskie Góry are located in the central part of the Silesian
Upland (Kondracki, 2011). Moreover, Zabrze is situated in the western part of the Upper Silesian Coal Basin (USCB), Dąbrowa Górnicza - in its eastern part and Tarnowskie Góry - in the border zone between the USCB and the Silesian-Kraków Monocline (Bukowy, 1974; Jureczka et al., 2005; Fig. 1). The USCB area is built of Upper Carboniferous sediments, which crop out in its central part. In the northern margin of the USCB, these strata are covered with Triassic sediments, which belong to the geological unit named the "Silesian-Kraków Monocline". In that area, some patches of Quaternary sediments occur, as well (Fig. 2).

The Carboniferous (Silesian) sediments outcropped in the vicinity of the "Guido" Mine and the "Królowa Luiza" Adit in Zabrze, and around the "Sztygarka" Training Mine in Dąbrowa Górnicza, comprise three Upper Carboniferous units traditionally named the "series": the Paralic Series (Namurian A), the Upper Silesian Sandstone Series (Namurian B and C) and, only around Dąbrowa Górnicza, the Mudstone Series (Westphalian B) (Wilanowski et al., 2009; 2015; Wilanowski, 2016; Tab. 1; Figs. 2A-2B).

Table 1. Schematic stratigraphy and lithology of sediments in the central part of the Upper Silesian Coal Basin area (after Żero, 1968; Wilanowski et al., 2009; 2015; Wilanowski, 2016)

\begin{tabular}{|c|c|c|c|c|}
\hline Stratigraphy & Series & Beds & Lithology and thickness & $\begin{array}{l}\text { Mining tourism } \\
\text { objects described } \\
\text { in the text }\end{array}$ \\
\hline Quaternary & - & - & $\begin{array}{l}\text { glacial and alluvial sediments } \\
\text { (total thickness: } 10-20 \mathrm{~m} \text { ) }\end{array}$ & - \\
\hline \multirow{2}{*}{ Middle Triassic } & \multirow{2}{*}{-} & $\begin{array}{l}\text { Jemielnica, } \\
\text { Tarnowice, Rybna, } \\
\text { Boruszowice, } \\
\text { Miedary beds }\end{array}$ & $\begin{array}{l}\text { limestones, dolomites, clay- } \\
\text { stones, mudstones, shales (total } \\
\text { thickness: } 190 \mathrm{~m} \text { ) }\end{array}$ & - \\
\hline & & $\begin{array}{l}\text { Błotnica, Gogolin } \\
\text { beds }\end{array}$ & $\begin{array}{l}\text { limestones (thickness: } 40 \mathrm{~m} \text { ), } \\
\text { ore-bearing dolomites (thickness: } \\
60 \mathrm{~m} \text { ) }\end{array}$ & $\begin{array}{l}\text { Historical Silver } \\
\text { Mine and "Czarny } \\
\text { Pstrąg” Adit in } \\
\text { Tarnowskie Góry }\end{array}$ \\
\hline $\begin{array}{l}\text { Upper Carboniferous - } \\
\text { Westphalian B }\end{array}$ & Mudstone Series & Orzesze Beds & $\begin{array}{l}\text { clastic sediments (total thickness: } \\
150 \mathrm{~m} \text { ) with coal seams (average } \\
\text { cumulative thickness: } 9 \mathrm{~m} \text { ) }\end{array}$ & \multirow{2}{*}{$\begin{array}{l}\text { "Sztygarka" } \\
\text { Training Mine in } \\
\text { Dąbrowa Górnicza }\end{array}$} \\
\hline $\begin{array}{l}\text { Upper Carboniferous - } \\
\text { Namurian C }\end{array}$ & $\begin{array}{l}\text { Upper Silesian Sandstone } \\
\text { Series }\end{array}$ & Rudy Beds & $\begin{array}{l}\text { mudstones, claystones (total } \\
\text { thickness: } 530 \mathrm{~m} \text { ) with coal } \\
\text { seams (average cumulative } \\
\text { thickness: } 15-20 \mathrm{~m} \text { ) }\end{array}$ & \\
\hline $\begin{array}{l}\text { Upper Carboniferous - } \\
\text { Namurian B }\end{array}$ & $\begin{array}{l}\text { Upper Silesian Sandstone } \\
\text { Series }\end{array}$ & Anticlinal Beds & $\begin{array}{l}\text { conglomerates, sandstones, } \\
\text { mudstones, claystones (total } \\
\text { thickness: } 80-320 \text { m) with coal } \\
\text { seams (average cumulative } \\
\text { thickness: } 28 \mathrm{~m} \text { ) }\end{array}$ & $\begin{array}{l}\text { "Królowa Luiza" } \\
\text { Adit in Zabrze }\end{array}$ \\
\hline $\begin{array}{l}\text { Upper Carboniferous - } \\
\text { Namurian A }\end{array}$ & Paralic Series & Poręba Beds & $\begin{array}{l}\text { claystones, mudstones, sand- } \\
\text { stones (total thickness: } 3,800 \mathrm{~m} \text { ) } \\
\text { with coal seams (average cumu- } \\
\text { lative thickness: over } 150 \mathrm{~m} \text { ) }\end{array}$ & $\begin{array}{l}\text { "Guido" Mine in } \\
\text { Zabrze }\end{array}$ \\
\hline
\end{tabular}






$1[\mathrm{~km}]$

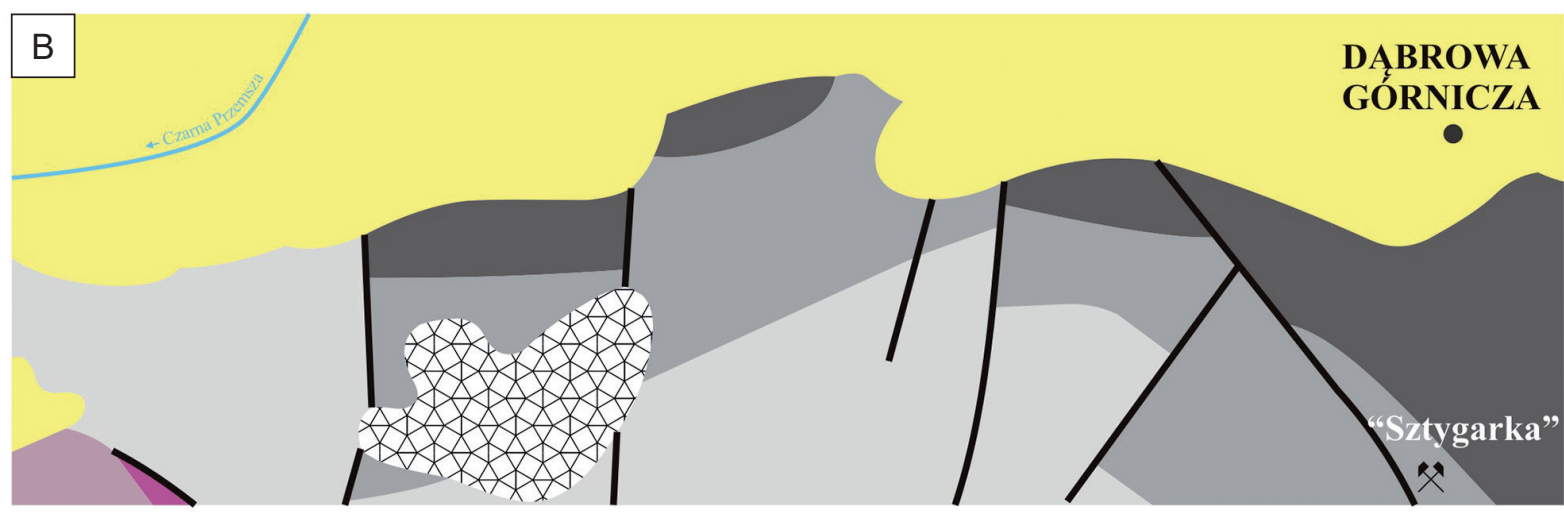

0

$1[\mathrm{~km}]$

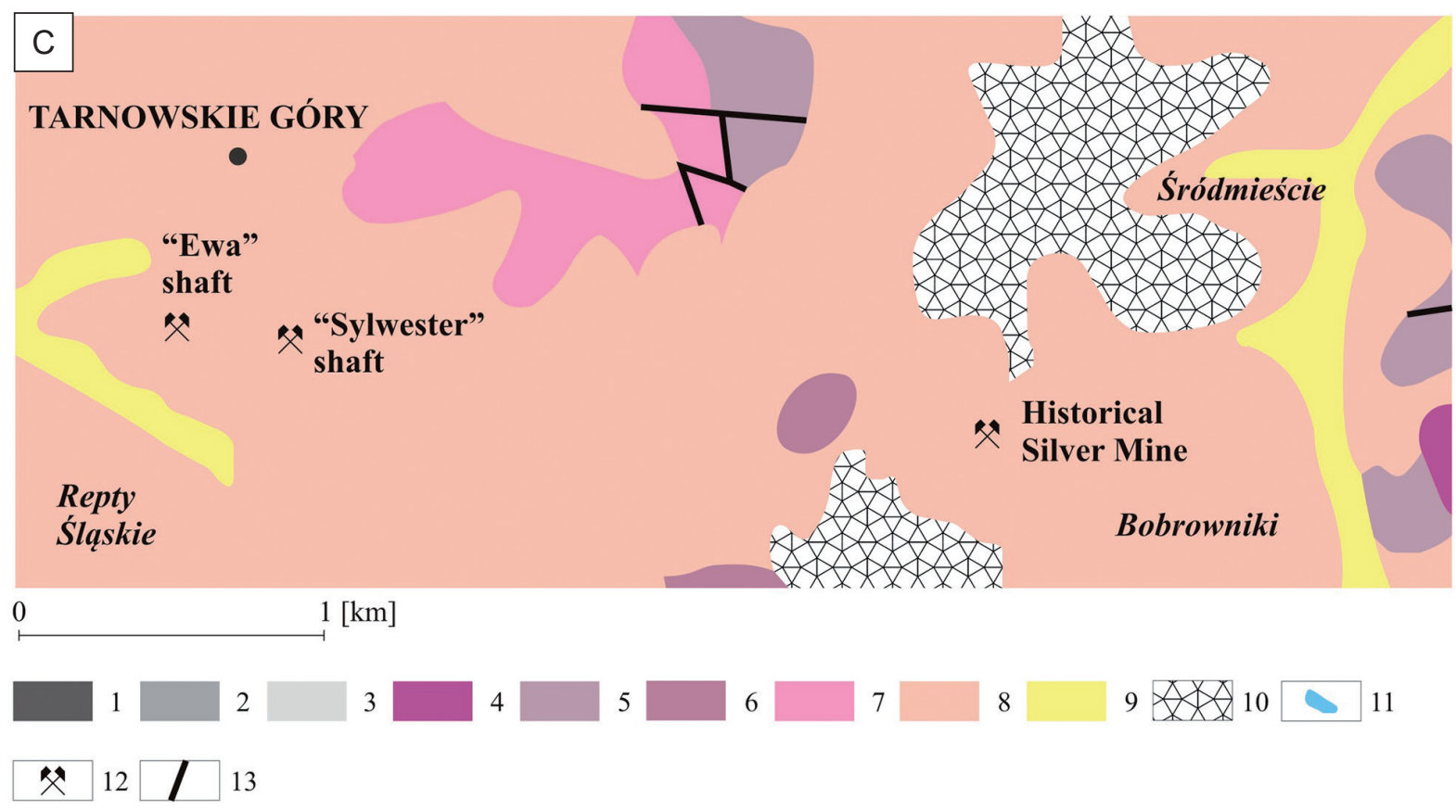

Fig. 2. Simplified geological sketch maps: A - Zabrze area; B - Dąbrowa Górnicza area; C - Tarnowskie Góry area (after Wilanowski et al., 2009; Wilanowski, 2016; Wilanowski \& Lewandowski, 2016). Explanations: Upper Carboniferous: 1 - Poręba Beds: claystones, mudstones, sandstones and coal seams; 2 - Anticlinal and Rudy Beds: sandstones and coal seams; 3 - Orzesze Beds: mudstones, claystones, sandstones and coal seams; Middle Triassic: 4 - Błotnica and Gogolin Beds: limestones; 5 - Ore-bearing Dolomite; 6 - Jemielnice and Tarnowice Beds: dolomites and limestones; 7 - Rybna, Boruszowice and Miedary Beds: limestones, dolomites, clays, claystones, mudstones and shales; Quaternary - Pleistocene: 8 - glacial sands, gravels and loams; Holocene: 9 - fluvial sediments; 10 - mining waste dump; 11 - reservoir; 12 - location of historical mines/adits/shafts; 13 - faults 
The area around Tarnowskie Góry town is built mainly of Middle Triassic sediments hosting metal ore deposits (Tab. 1; Fig. 2C). The ore-bearing dolomite is the host rock to lead and zinc minerals. Galena $(\mathrm{PbS})$ is the most common lead mineral occurring in the Silesian Upland and the carrier of silver admixtures, especially in the Tarnowskie Góry ore deposits (Gabzdyl, 1999; Tab. 1; Fig. 2C). In general, the carbonate rocks around Tarnowskie Góry town are strongly karstified (Żero, 1968; Wilanowski \& Lewandowski, 2016).

\section{Historical coal mining in Zabrze town}

In Zabrze, some parts of the two historical mines have been opened for tourists and have become geotourism attractions: the "Królowa Luiza" Adit and the "Guido" Mine (Drobniak et al., 2020; Gola, 2020; www3; www6; Fig. 2A).

The "Królowa Luiza" Mine has been developed in 1791 due to high demand for coal from the intensively growing Upper Silesian metallurgical industry. First ironworks have started operations in 1784, in Strzybnica, which is now a district of Tarnowskie Góry town (Dzięgiel, 2007; Gola, 2020). Bituminous coal seams were extracted in a number of surface excavations and underground workings. The shafts were sunk down to the depths from 30 to $800 \mathrm{~m}$ below surface.

For the first time the "Królowa Luiza" Mine had been opened to the public in the years 1965-1979. Visitors could observe the operation of mechanized longwall, located close to the Carnall Shaft (www4; Fig. 3). This industrial tourism attraction was managed by the Intercompany Mining Branch of the Polish Tourist and Country-Lovers' Association. Over 10,000 tourists a year visited the mine in that period. However, in 1979, it had to be closed to the public because of some mine safety problems (www4).

In 1998, the mine has halted production because of reserves exhaustion. However, as early as in the late 1980s, in its inactive parts located around the "Wilhelmina" and the "Carnall" shafts (Fig. 3), the Coal Mining Museum in Zabrze has established one of its branches named "The Królowa Luiza Mining Open-Air Museum" comprising selected mine workings. It has been available to the visitors since 1993 (Dzięgiel, 2007; Żurek et al., 2010; Frużyński, 2012; Gola, 2020). Currently, this trail is called the "Family Route" of the "Królowa Luiza" Adit (Gola, 2020; www4; Fig. 3).

Since 2018, “The Queen Louise Mining Open-Air Museum" has been integrated with the final section of the old Main Key Hereditary Adit (Jurkiewicz, 2002; Jurkiewicz et al., 2009). This is an underground tunnel, which development had lasted from 1799 to 1863 . Its task was to drain the coal mines "Królowa Luiza" in Zabrze and "Król" ("King”) in Chorzów, and the other, neighbouring ones, as well as to transport the coal from the "Królowa Luiza" to the steelworks in Gliwice town through the Kłodnica Canal. Unfortunately, the growth of mining industry and the progress in water-pumping technologies, together with the exhaustion of shallow coal deposits contributed to relatively quick decline of the importance of this adit. It finally stopped operation in 1953. In order to regain the adit for tourists, the Society for the Restoration and Promotion of the "Królowa Luiza" Adit in Zabrze, "Pro Futuro", has been established in 2000 (Gałązka-Salamon, 2012). Local authorities of Zabrze town implemented a consistent promotion strategy based on principles of the industrial heritage tourism. Therefore, they decided to revitalize and adapt for tourism the final section of the Main Key Hereditary Adit and to connect it with the "Królowa Luiza" old underground workings (Jurkiewicz et al., 2009; Żurek et al., 2010; Bugaj \& Glosz, 2012; Gola, 2020). Thus, since 2018 the "Królowa Luiza" Adit has been the site of two underground tourist trails: the "Water Route" and the "Family Route" (Figs. 3, 4A-4D) (Gola, 2020; www3).

The "Water Route" (www7; Fig. 3) is one of the most amazing underground tourist trails in Poland. The visitors pass its first section on foot through the original $19^{\text {th }}$ century drift, about $1 \mathrm{~km}$ long, cut $40 \mathrm{~m}$ below the surface. The drift is cut, entirely within the 6-m-thick coal seam No. 510 (in Polish coal seams identification system) belonging to the Upper Silesian Sandstone Series (Wilanowski et al., 2009; 2015; Tab. 1). The visitors can observe a mining face worked in No. 510 coal seam, with roof support of the upper coal bench built of timber racks (Fig. 4A). The last section of the route, $1,130 \mathrm{~m}$ long, is a unique underground boat trip (Fig. 4B). It runs along the stone-lined, former Main Key Hereditary Adit illuminated by special lighting system and leads to the adit mouth located in the center of Zabrze (www3; Fig. 3).

The "Family Route" (www7; Fig. 3) is situated $35 \mathrm{~m}$ below surface and runs along a $1.5-\mathrm{km}$-long gallery. This is an extraordinary adventure, combining the observations of the authentic mine workings with the views of huge mining machines, and providing fun and educating experience for the youngest tourists. The visitors can examine the coal shearer operating along the long wall and protected by self-advancing supports (Fig. 4C). At the end of the trail, the visitors can travel with the historical underground train named "Karlik" (Fig. 4D), which carries them along some 1.5-km-long crosscut. The crosscut of that railway ride is lined with steel arches (Fig. 4D).

In the future, the third underground route in the "Królowa Luiza" Adit is to be opened to the public, connecting the "Carnall" and the "Wilhelmina" shafts (Fig. 3; www4).

The "Guido" Mine (Fig. 2A) has been in operation since 1855. It included a system of workings and shafts cut down to $300 \mathrm{~m}$ depth below surface. Coal was extracted until the 1930s. In 2007, the local authorities decided to open for tourism some selected old workings (Figs. 4E-4H) (Walerjański, 2008; Walerjański \& Szczypkowska, 2010; Dzięgiel, 2011). Underground tourist trails are located at two former mining levels: $170 \mathrm{~m}$ and $320 \mathrm{~m}$ below surface (Frużyński, 2012; Piątek, 2013). 


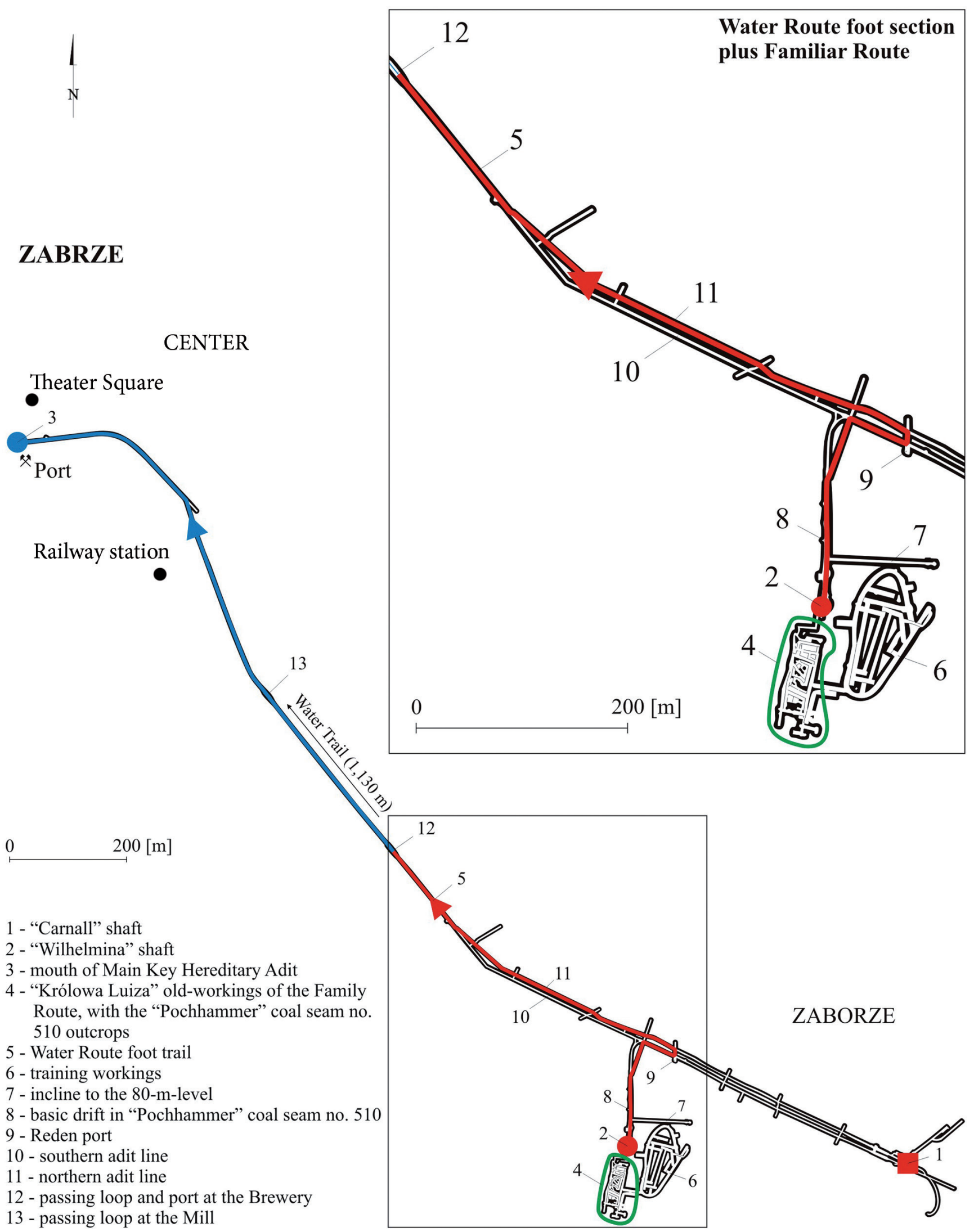

Fig. 3. Map of the "Królowa Luiza” Adit (after Chybiorz, 2018) 

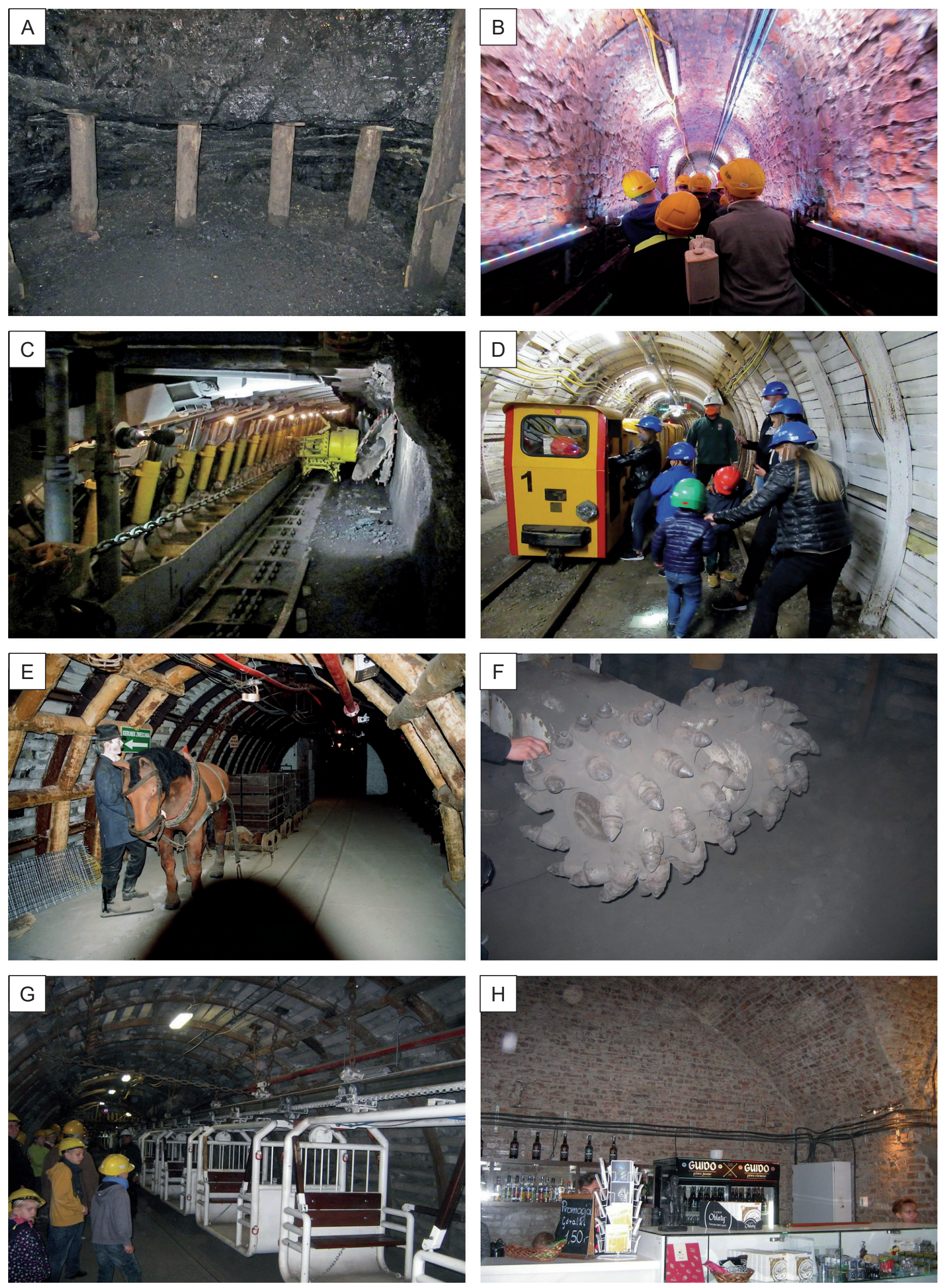

Fig. 4. Photographs of the "Królowa Luiza" Adit and the "Guido" Mine. Explanations: Water Route: A - mining face cut in the "Pochhammer" coal seam No. 510 with roof of the upper coal bench supported with timber racks; B - underground boat trip along the "Królowa Luiza" Adit with sandstone lining, illuminated by special lighting system; Family Route: C - presentation of longwall mining system: shearer, self-advancing support and face conveyor; D - electric train, one of the most common means of underground transport of miners, coal and equiment; "Guido" Mine, $170 \mathrm{~m}$ mining level: E - Ventilation Crosscut and mine carts pulled by horses; $320 \mathrm{~m}$ level: $\mathrm{F}$ - cutter drum of long-wall shearer; $\mathrm{G}$ - electric suspension train; $\mathrm{H}$ - the deepest-seated pub in Europe. All photos after M. Dzięgiel 
The tourist trail at the $170 \mathrm{~m}$ level enables the visitors to walk along the Ventilation Crosscut where they visit a $19^{\text {th }}$ century horse stable. Horses were used for pulling the hauling carts. The crosscuts are lined with wooden bars and steel arches (Fig. 4E). At the end of this crosscut, there are some rooms with the exhibition of old mining tools, lamps, rescue equipment and maps presenting traditional coal exploitaion systems. There is also a small geological museum and St. Barbara Chapel.

At $320 \mathrm{~m}$ level, tourists walk through a network of historical workings: shafts, drifts, inclines and chambers where a collection of mining machinery is exposed. These are authentic devices used for coal extraction throughout the $19^{\text {th }}$ and the $20^{\text {th }}$ centuries. The drifts are partly lined with steel arcs and anchors. Total length of this trail is about $2.5 \mathrm{~km}$. Visitors can recognize the mining methods used in the $19^{\text {th }}$ century. They can also watch the operation of the conveyor belt protected by mixed roof support: steel props and timber posts with caps and the face shearer as well as some outcrops of coal seams of the Paralic Series (Wilanowski et al., 2009, 2015; Tab. 1; Figs. 2A and 4F). Since 2011, an additional adventure available for the visitors has been the only electric underground suspension rail in Poland (Fig. 4G) and a unique pub located in an old chamber (Fig. 4H). Quite a high number of concerts and theatrical performances are held there (www3). The Coal Mining Museum in Zabrze has also the exhibition of coal specimens from the USCB area (www3).

The interest in the two geotourism attractions in Zabrze was always very high. In the years 1995-2012, the total number of visitors varied from 45,107 up to 63,051, with an exception of 2005, when it decreased to 37,136 . However, in 2013, it dropped down to 5,591 (www8; Tab. 2). The underground trail of the "Królowa Luiza" Mine was closed in the years 2011-2017, because of restoration works. In 2014, the surface facilities of the mine have been opened for tourists. This explains a noticeable increase of attendants to the Zabrze "mining heritage sites". Since 2014, the number of visitors to these two geotourist attractions in Zabrze has rised from 121,483 up to 182,374 . Since the two new underground trails of the "Królowa Luiza" Adit have been developed for tourism: the "Familiar Route" (since 2016) and the "Water Route" (since 2018), the total number of visitors to all three sites in Zabrze have increased up to the top value of 223,820 in 2019 (www8; Tab. 2).

In 2020, the "Królowa Luiza" Adit and the "Guido" Mine were recognized by the President of the Republic of Poland as a monument of history under the name of the "Zabrze - a Complex of Historic Coal Mines". Thus, these were included into the most valuable historical buildings in Poland. Owing to its international importance, Zabrze town now plays the role of the European centre of industrial heritage, related to the "black gold" historical mining (Gola, 2020).
Table 2. Annual numbers of visitors to the selected geotourism attractions in Zabrze, Dąbrowa Górnicza, Wieliczka, Złoty Stok and Nowa Ruda (after Kruczek \& Szromek, 2011; Kruczek, 2019; www8)

\begin{tabular}{|c|c|c|c|c|c|}
\hline 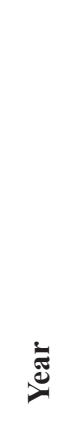 &  & 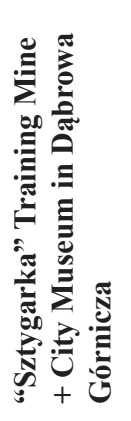 & 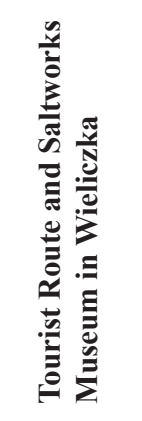 & 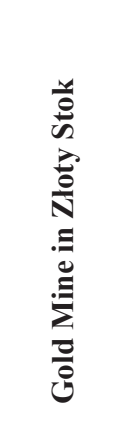 & 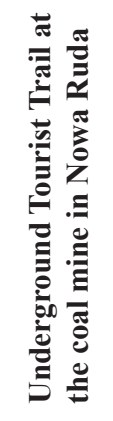 \\
\hline 1995 & 49,462 & - & 500,000 & - & - \\
\hline 1996 & 52,366 & - & 540,000 & \multirow{15}{*}{ No data } & \multirow{15}{*}{ No data } \\
\hline 1997 & 57,287 & - & 560,000 & & \\
\hline 1998 & 51,702 & 3,082 & 580,000 & & \\
\hline 1999 & 52,491 & 2,644 & 600,000 & & \\
\hline 2000 & 63,051 & 3,435 & 640,000 & & \\
\hline 2001 & 58,100 & 4,034 & 700,000 & & \\
\hline 2002 & 57,164 & 5,654 & 750,000 & & \\
\hline 2003 & 48,323 & 3,306 & 820,000 & & \\
\hline 2004 & 47,393 & 3,826 & 870,000 & & \\
\hline 2005 & 37,136 & 1,523 & 920,000 & & \\
\hline 2006 & 46,337 & 1,150 & 960,000 & & \\
\hline 2007 & 45,107 & 2,457 & 980,000 & & \\
\hline 2008 & 52,487 & 5,320 & $1,000,500$ & & \\
\hline 2009 & 59,799 & 4,682 & $1,000,200$ & & \\
\hline 2010 & 60,084 & 5,826 & 990,000 & & \\
\hline 2011 & 46,939 & 8,800 & $1,060,957$ & 145,000 & 30,365 \\
\hline 2012 & 51,852 & 12,323 & $1,117,158$ & 155,000 & 32,149 \\
\hline 2013 & 5,591 & 12,317 & $1,209,708$ & 175,000 & 35,765 \\
\hline 2014 & 156,423 & 16,951 & $1,178,601$ & 250,000 & 40,000 \\
\hline 2015 & 121,483 & 14,187 & $1,279,341$ & 185,000 & 50,000 \\
\hline 2016 & 161,641 & 14,645 & $1,474,383$ & 217,000 & 50,000 \\
\hline 2017 & 162,856 & 19,294 & $1,710,692$ & 214,000 & 50,000 \\
\hline 2018 & 182,374 & 18,997 & $1,911,186$ & 211,000 & 50,000 \\
\hline 2019 & 223,820 & 10,717 & $1,863,000$ & No data & No data \\
\hline
\end{tabular}




\section{The "Sztygarka" Training Mine in Dąbrowa Górnicza town}

The "Sztygarka" Training Mine is located in the southeastern part of the former "Paris" coal mine in Dąbrowa Górnicza town (Fig. 1). The "Paris" Mine has been established in 1876, by merging the "Labęcki" Mine, existing since 1865, and the "Nowa" Mine, in operation since 1867 (Ciepiela, 2007; Bielecki, 2008).

In 1889, the Mining School has been established in Dąbrowa Górnicza, as a secondary technical school dedicated to education and practical training of foremen for mines, smelters and ironworks. In 1919, the school evolved into the State Mining and Metallurgical School, known under the nickname of "Sztygarka" ("sztygar" in Polish means "foreman" and "sztygarka" is a slang name of chamber, in which foremen work). Practical training required underground workings, hence, since 1927, a system of galleries has been cut at 10-15 m depth below surface (Wójcik \& Chmura, 2008; Cygnarowska, 2017).

The practical training at the "Sztygarka" Mine has ceased in 1994. The "Paris" Mine was closed in 1995 due to reserves' exhaustion. In the following years, the local authorities debated the adaptation of existing mine workings for a mining museum, as it was the only existing remnant documenting the long history of mining activity in Dąbrowa Górnicza. Hence, the "Sztygarka" Training Mine was adapted for tourism in 2010 (Chmura \& Wójcik, 2009; Glimos-Nadgórska, 2017; www2).

The "Sztygarka" Training Mine has become a branch of the "Sztygarka" City Museum (Sobota, 2007; Cygnarowska, 2017; www2), founded in 1997 and situated in its close neighbourhood (Fig. 5). Tourists can walk along selected old workings of total length about $650 \mathrm{~m}$, cut at two mining levels vertically spaced by about $14 \mathrm{~m}$ and interconnected with the northern incline No. I (Duży \& Preidl, 2011; Figs. 5, 6). The deepest No. III level, (Figs. 5, 6A), is currently inaccessible for visitors. At the upper, No. I level, in the southern drift (Figs. 5, 6A), visitors can see the brick lining (Fig. 7A) and a collection of various types of mine carts used for coal haulage (Fig. 7B). In the western drift (Figs. 5, 6A), ventilator and fully equipped electric switchboard are exhibited. When walking along the northern incline (Figs. 5, 6B), the tourists recognize the ventilation pipe delivering fresh air to the workings (Fig. 7C).

At the lower, No II level, in the overwall drift (Fig. 5), tourists can see the outcrop of a coal seam belonging to the Rudy Beds (Wilanowski, 2016; Tab. 1; Fig. 7E). The overwall drift has a steel arc lining (Fig. 7D). The No. II longwall, started at the beginning of the southern incline (Fig. 5), is equipped with a shearer (Fig. 7F) and a conveyor belt (Fig. 7G) whereas its roof is protected by steel arches and hydraulic props (Fig. 7G).
In the "Sztygarka" City Museum, visitors can also examine the collection of coal specimens taken from various outcrops within the Upper Silesian Coal Basin area (Fig. 7H).

Despite the fact that the underground trail at the "Sztygarka" Training Mine is much shorter than the other such objects in Zabrze, the interest in this facility and the City Museum was always very high. They have become a geotourism attraction widely known in Poland and in the world. In the years 1998-2009, total number of visitors to the "Sztygarka" City Museum varied from 1,150 to 5,654 (www8; Tab. 2). When the underground trail has been opened for public in 2010, a noticeable increase was observed of total number of tourists visiting these two facilities: from 12,317 up to 19,294 . However, in 2019, the number decreased to 10,717 (www8; Tab. 2). When the tourist trail at the "Sztygarka" Training Mine is extended by opening the drifts at No. III level (Polko, 2018; Figs. 5, 6A), the significant increase of tourist flow is expected.

\section{Historical lead-zinc-silver ore mining in Tarnowskie Góry town}

The ore mining in Tarnowskie Góry town dates back to around 1490. These mineral resources were the basis for metallurgical industry in Poland and in Central Europe (Pawlak \& Filak, 2017). Large number of surface excavations, shafts and galleries were cut in Triassic dolomites, in order to reach silver, lead and (later) zinc orebodies. Total length of these old-workings is about $150 \mathrm{~km}$. At the beginning, only primitive, manual methods were used with hammer as the most popular rock-cutting tool. The output was transported to the shaft stations and hoisted in kibbles. The galleries had to be drained when operations were run beneath the groundwater table. Hence, kibbles were used for draining the mine, but inflows were too high due to karstification of dolomites. Thus, special drainage adits had to be cut. In addition, horse-driven windlasses were used for mine drainage, as well. In the $17^{\text {th }}$ century, ore exploitation ceased due to the Thirty Years' War and later Prussian-Austrian war in the Silesia. In 1784, a new "Fryderyk" ("Frederick") mine was constructed in Tarnowskie Góry. Its workings were drained by water adits (Moszny, 2003). The last adit, named the "Głęboka-Fryderyk" ("Deep-Frederick", recently the "Czarny Pstrąg" Adit) was cut between 1821 and 1835. Its small part, about 600-m-long, has been adapted for tourism (Piernikarczyk, 1984; Dzięgiel, 2008; www4).

The ore mining in Tarnowskie Góry was stopped in 1922 due to reserves' exhaustion (Szlachcic-Dudzicz, 2006; Dzięgiel, 2008; Wyciszczak, 2008; Pawlak \& Filak, 2017). 


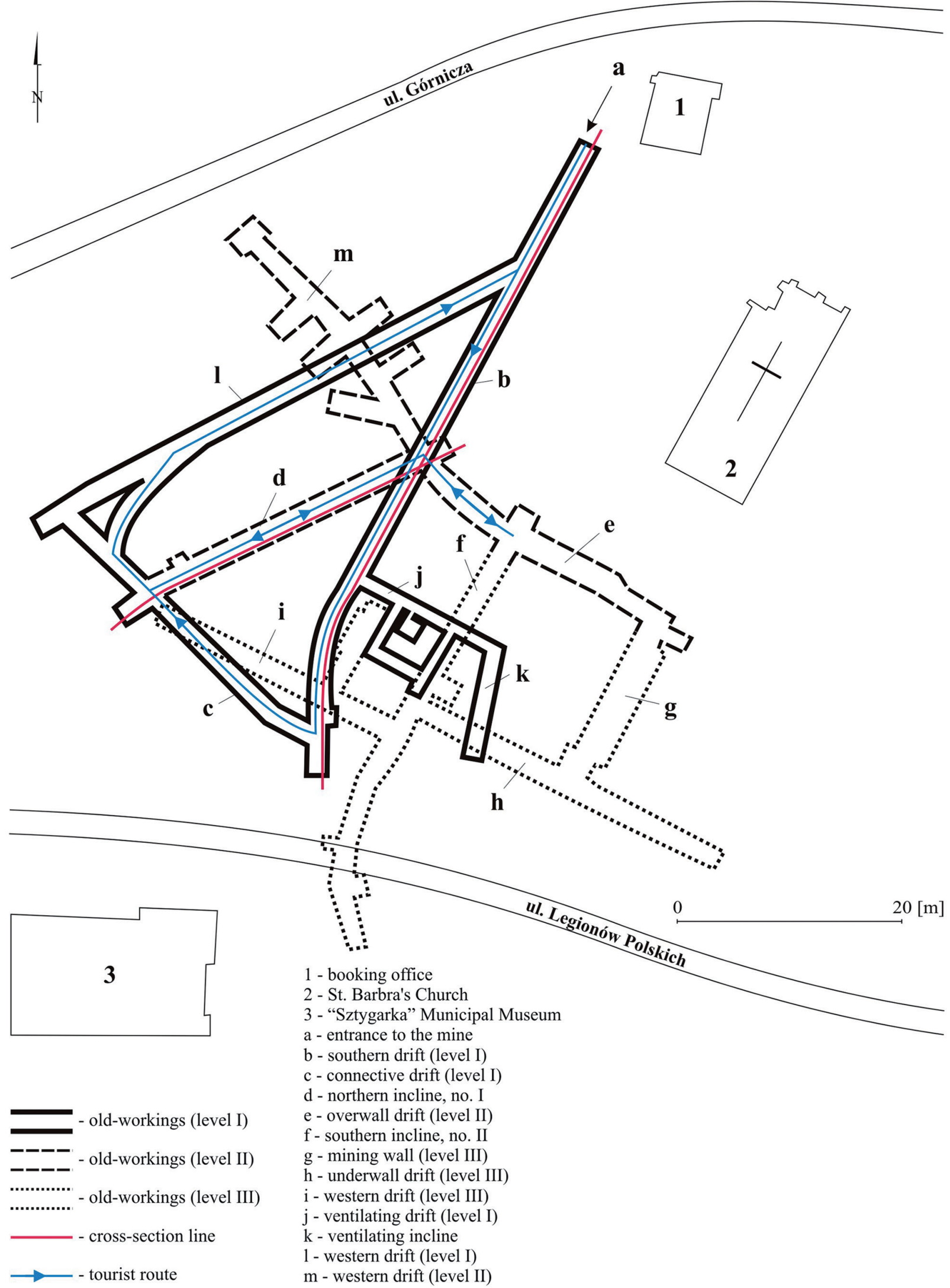

Fig. 5. Map of the "Sztygarka" Training Coal Mine workings (after Duży \& Preidl, 2011) 
NE

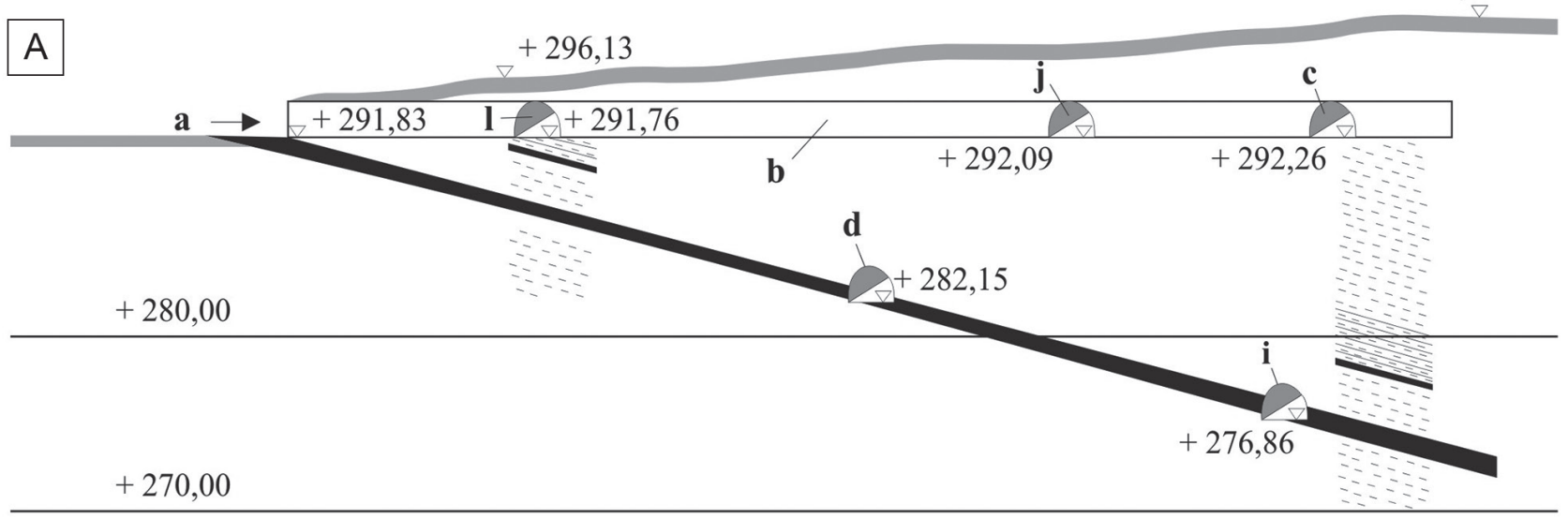

$20[\mathrm{~m}]$

NE

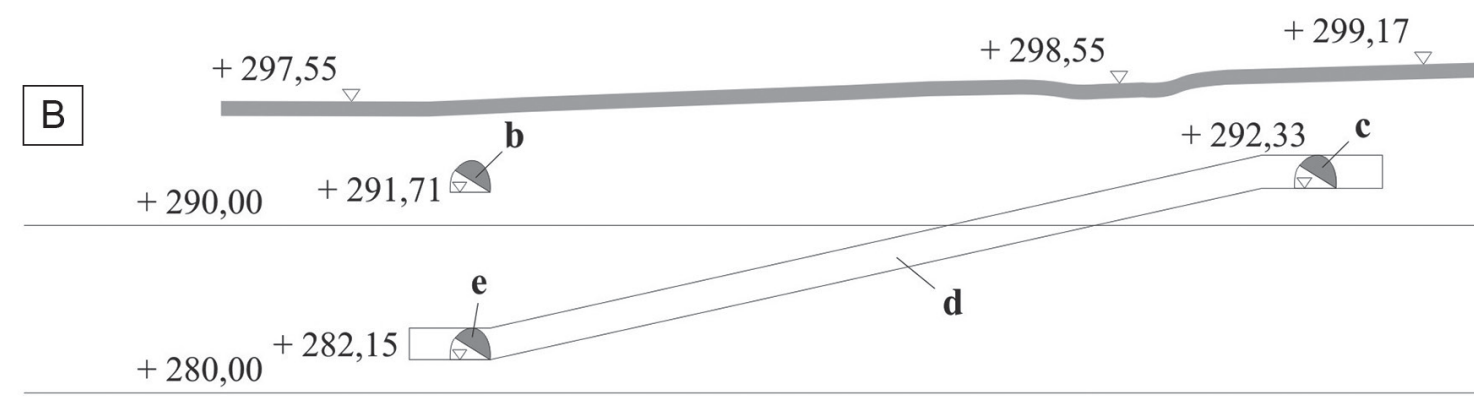

0 $20[\mathrm{~m}]$

\footnotetext{
(2)

- ground surface

$\mathrm{a}$ - entrance to the mine

b - southern drift (level I)

c - connective drift (level I)

d - northern incline, no. I

e - overwall drift (level II)

i - western drift (level III)

$\mathrm{j}$ - ventilating drift (level I)

1 - western drift (level I)
} coal seams - Upper Carboniferous, Namur C, Rudy Beds (Tab. 1)

- claystone - Upper Carboniferous, Namur C, Rudy Beds (Tab. 1)

- mudstone - Upper Carboniferous, Namur C, Rudy Beds (Tab. 1)

Fig. 6. Cross-section through the "Sztygarka" Training Coal Mine working (Fig. 7) with geological sequences along the southern drift (A) and the northern incline No. I (B) (after Duży \& Preidl, 2011) 

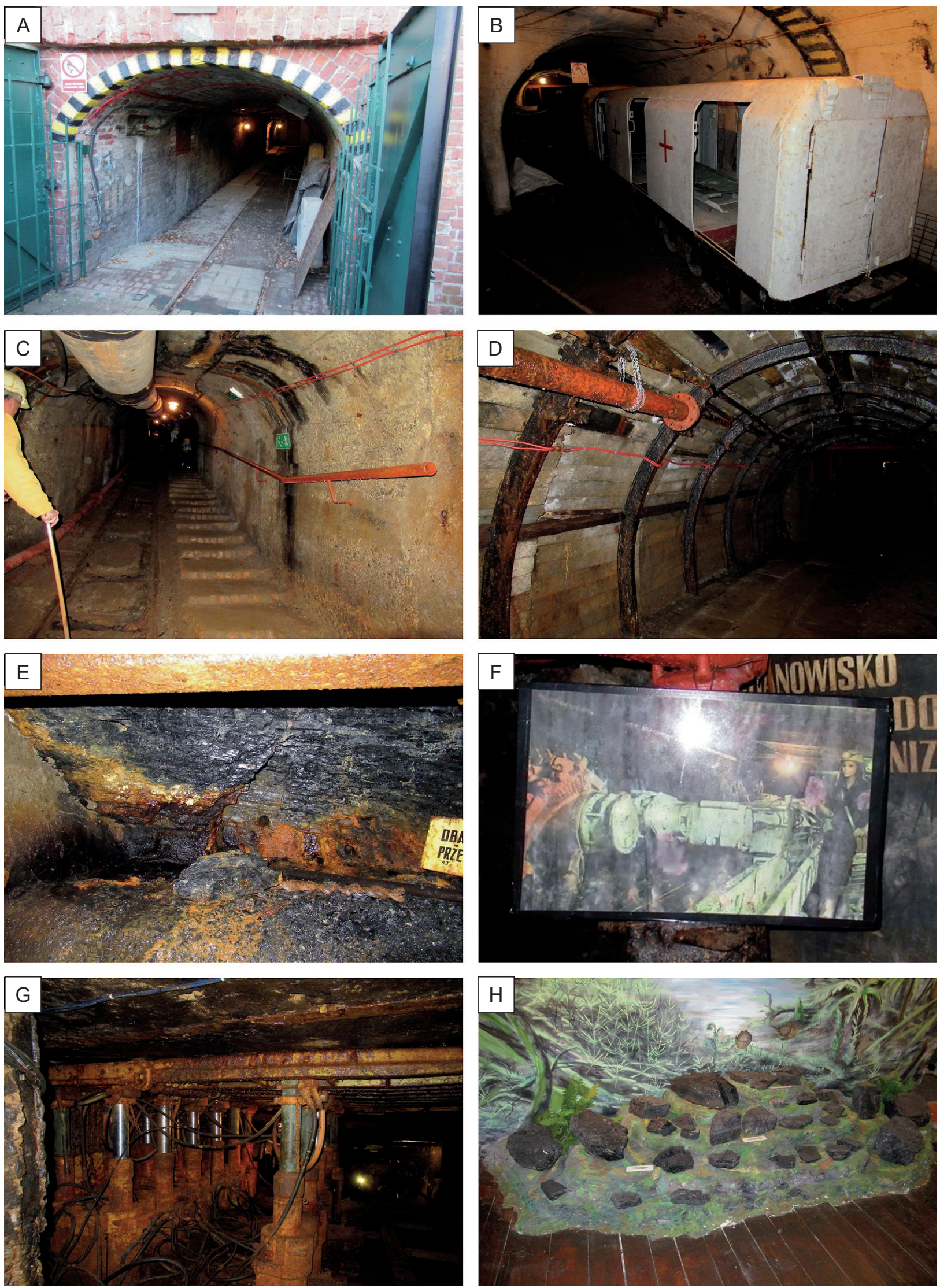

Fig. 7. Photographs of the "Sztygarka" Training Mine. Explanations: A - entrance to the mine; B - mine carts in southern drift (mining Level I); C - northern No. I incline; D - sidewalk lined with metal arches in overwall drift (mining Level II); E - coal seam outcrop in overwall drift wall (Level II); F - shearer in southern No. II incline (mining Level II); G - hydraulic props of powered roof support in southern No. II incline, (mining Level II); H - coal specimens from the Upper Silesian Coal Basin exhibited in the "Sztygarka" City Museum. All photos after M. Dzięgiel 
In 1953, the Tarnowskie Góry Land Lovers Association has been founded and it has started the arrangement of some part of the old ore mine old-workings for tourism. Finally, the "Czarny Pstrąg" Adit has become accessible to the public since 1957 and the Historical Silver Mine has started operation since 1976 (www4; Fig. 2C).

The Historical Silver Mine is located around the "Aniol" ("Angel") Shaft (Fig. 8A), about $40 \mathrm{~m}$ below surface (Szlachcic-Dudzicz, 2006; Dzięgiel, 2008). The tourist trail is 1,740 m long and connects three shafts: "Anioł", "Szczęść Boże" ("God Bless You") and "Żmija" ("Viper"). The most important stops along the exposed old workings are: the outcrop of an accumulation of sulphide minerals (mostly galena) with some veinlets protruding into the surrounding, weathered, Middle Triassic, ore-bearing dolomite in the Collapse Chamber (Fig. 8B), the "Szczęść Boże” Shaft (Fig. 8C) and about 270-m-long gallery connecting it with the "Żmija" Shaft. The visitors row along that gallery by boat (Dzięgiel, 2008; Fig. 8D). There is also a mining museum in the building of the "Aniol" Shaft (Fig. 8A).

The second underground geotourism attraction in Tarnowskie Góry is the "Czarny Pstrąg" Adit (Piernikarczyk, 1984; Moszny, 2003; Dzięgiel, 2008; Wilanowski \& Lewandowski, 2016; Figs. 8E-8F). The visitors walk down the "Sylwester" Shaft (Fig. 8E) to the gallery, $30 \mathrm{~m}$ below surface and then row by boat about $600 \mathrm{~m}$ along the adit (Fig. 8F) to the "Ewa" Shaft. The adit was cut in the Middle Triassic ore-bearing dolomite (Fig. 8F). Finally, the tourists walk up the staircase from ca $20 \mathrm{~m}$ depth to the surface.

Until now, these two underground trails have been managed by the Tarnowskie Góry Land Lovers Association (www4), and in 2004 the objects were recognised by the President of the Republic of Poland as a monument of history owing to their exceptional values and authenticity. Currently, these objects also belong to the group of 28 different venues in Tarnowskie Góry, Zbrosławice and Bytom called "The Tarnowskie Góry Lead-Silver-Zinc Mine and its Underground Water Management System", which were included into the UNESCO World Heritage List in 2017 (Pawlak \& Filak, 2017; Ziarkowska, 2019). That success was achieved thanks to the five-years-long efforts of the Tarnowskie Góry Land Lowers Association, in cooperation with many foreign organizations related to industrial heritage preservation (www1).

The tourism statistics for the Historical Silver Mine and the "Czarny Pstrąg" Adit in the years 1958-2018 recorded by the Tarnowskie Góry Land Lovers Association (Ziarkowska, 2019; www4) has reflected the great interest in these sites since the beginning of their adaptation for tourism (Tab. 3). The "Czarny Pstrąg" Adit has been the first to be opened for public in Tarnowskie Góry in 1957. During the first two years, the tourist attendance was rather low, up to 6,432 persons. But in the following years, until 1975, the adit has been visited by many more people: from 12,922 to 53,637 per year. Only in 1962, this figure decreased to 10,600 (Tab. 3).
Table 3. Combined annual numbers of visitors to geotourism attractions - the Historical Silver Mine and the "Czarny Pstrąg" Adit in Tarnowskie Góry (after Ziarkowska, 2019)

\begin{tabular}{|c|c|c|c|}
\hline Year & Visitors number & Year & Visitors number \\
\hline 1958 & 1,800 & 1989 & 128,583 \\
\hline 1959 & 4,631 & 1990 & 114,649 \\
\hline 1960 & 6,432 & 1991 & 116,122 \\
\hline 1961 & 12,922 & 1992 & 153,840 \\
\hline 1962 & 10,600 & 1993 & 142,847 \\
\hline 1963 & 15,752 & 1994 & 159,256 \\
\hline 1964 & 20,206 & 1995 & 165,267 \\
\hline 1965 & 22,873 & 1996 & 142,793 \\
\hline 1966 & 26,092 & 1997 & 163,883 \\
\hline 1967 & 33,500 & 1998 & 147,152 \\
\hline 1968 & 41,456 & 1999 & 147,084 \\
\hline 1969 & 44,287 & 2000 & 142,378 \\
\hline 1970 & 50,241 & 2001 & 105,574 \\
\hline 1971 & 45,794 & 2002 & 124,925 \\
\hline 1972 & 46,177 & 2003 & 108,867 \\
\hline 1973 & 46,796 & 2004 & 108,516 \\
\hline 1974 & 48,607 & 2005 & 105,350 \\
\hline 1975 & 53,637 & 2006 & 108,024 \\
\hline 1976 & 48,776 & 2007 & 119,527 \\
\hline 1977 & 79,081 & 2008 & 119,138 \\
\hline 1978 & 88,021 & 2009 & 98,605 \\
\hline 1979 & 84,992 & 2010 & 75,475 \\
\hline 1980 & 88,887 & 2011 & 87,768 \\
\hline 1981 & 77,862 & 2012 & 96,051 \\
\hline 1982 & 71,973 & 2013 & 96,218 \\
\hline 1983 & 88,879 & 2014 & 115,677 \\
\hline 1984 & 108,030 & 2015 & 103,208 \\
\hline 1985 & 94,937 & 2016 & 122,493 \\
\hline 1986 & 119,994 & 2017 & 131,355 \\
\hline 1987 & 122,966 & 2018 & 138,287 \\
\hline 1988 & 117,688 & & \\
\hline
\end{tabular}





Fig. 8. Photographs of the Historical Silver Mine (HSM) and the "Czarny Pstrąg" Adit (CPA). Explanations: A - headframe of the "Aniol" Shaft (HSM); B - Collapse Chamber - sulphide minerals outcrop and mine carts (HSM); C - "Szczęść Boże" Shaft with water bucket a part of old mine drainage system (HSM); D - brick-lined gallery connecting the "Szczęść Boże" and the "Żmija” shafts (HSM); E - "Sylwester" Shaft (CPA); F - underground canal (CPA). All photos after M. Dzięgiel

The patients of the Upper Silesian Rehabilitation Center (in operation since 1961), situated near the adit were especially numerous among the visitors to the "Czarny Pstrąg" Adit. When the Historical Silver Mine was also opened for tourism in 1976, the total visitor number of both sites has increased noticeably, from 79,081 in 1977 to 88,887 in 1983. In 1984, the attendance exceeded, for the first time, 100,000 visitors (Tab. 3). The Historical Silver Mine was 
occassionally modernised in the past, which resulted in the increase of tourist attendance in the following years. From 1986 to 2018, annual number of visitors varied from 105,350 to 165,267 , except for the years 2009-2013 when the total attendance at these two facilities decreased slightly below 100,000 . But since 2014, the number of visitors has again exceeded 100,000 and achieved the values of 131,355 in 2017, and 138,287 in 2018 (Tab. 3). This last noticeable increase could be related to the entering the UNESCO World Heritage List in 2017 (Pawlak \& Filak, 2017; Ziarkowska, 2019).

\section{Conclusions}

Statistical data analysis of tourist flow in the underground trails of the central part of the Silesian Upland indicates that their geotourism attractiveness and popularity are very high. Currently, number of tourist visits to the Historical Silver Mine and the "Czarny Pstrąg" Adit in Tarnowskie Góry, and to the historical coal mines in Zabrze: the "Królowa Luiza" Adit and the "Guido" Mine are higher than those to the popular Coal Mine in Nowa Ruda town and, for a few years, have been almost equal to the attendance to the Gold Mine in Złoty Stok town (Tabs. 2, 3) (Kruczek \& Szromek, 2011; Ziarkowska, 2019; www8; www9). This perfectly documents the increasing dynamics of the tourist flow in the historical mines.

The geotourism attractions in Tarnowskie Góry were the first post-industrial underground mining heritage monuments in the Upper Silesia adapted for tourism in 1957 and 1976. Hence, since the 1980s, they have been visited more frequently than the historical coal mines in Zabrze and in Dąbrowa Górnicza (Tabs. 2, 3). As these sites have already been included into the UNESCO World Heritage List, the Tarnowskie Góry Land Lovers Association (www4) in cooperation with the local authority attempted to design the future Upper Silesian Metal Ore Mining Geopark. Owing to that, these facilities could become even more widely recognised all over the world.
The tourist visits at the "Królowa Luiza" Adit and the "Guido" Mine in Zabrze have increased noticeably only in the recent years (Tab. 1). Therefore, the local authorities, in cooperation with numerous foreign organizations associated with the industrial heritage protection and some other European international institutions, should make an effort to include also these objects into the UNESCO World Heritage List. This may help to make these sites more recognizable and to achieve an additional great success, despite the fact that Zabrze already plays a significant role as the European centre of industrial heritage related to the "black gold" mining. Hence, the local authorities may also attempt to develop the Upper Silesian Coal Mining Geopark. At the beginning, it could include only the two historical coal mines in Zabrze, but in the future, it may be extended to some other sites in the USCB area, when the recently operating mines cease their activity and their relics become accessible for visitors.

As a result of the creation of the Upper Silesian Metal Ore Mining and Coal Mining geoparks, some exchange of experiences and information concerning the restoration and modernization of the sites among local authorities can be much easier. This could lead to the increase of their global rank and reputation.

The "Sztygarka" Training Mine in Dąbrowa Górnicza is still much less known as a geotourism attraction than the other objects described above. First of all, this underground trail is much shorter than the others, except for the "Czarny Pstrąg" Adit. It has been the latest object, opened to the public in 2010 except for the two new trails developed later at the "Królowa Luiza" Adit. Hence, it could not be effectively promoted and, thus, so widely known, as yet. However, after extension of the trails at No. III mining level (Figs. 5, 6A) and after general restoration, the "Sztygarka" Training Mine will gain a potential to be much more popular in Poland and in the world, particularly if included into the future Upper Silesian Coal Mining Geopark. The perspectives of tourism development in the central part of the Silesian Upland, based upon their industrial heritage and geoheritage attractions of the central part of the Upper Silesian Coal Basin seem to be very optimistic.

\section{References}

Bielecki S., 2008. Kopalnie węgla kamiennego w Dąbrowie Górniczej (1785-1995). Towarzystwo Przyjaciół Dąbrowy Górniczej, Dąbrowa Górnicza.

Bugaj T. \& Glosz M., 2012. Główna Kluczowa Sztolnia Dziedziczna. Europejski Ośrodek Kultury Technicznej i Turystyki Przemysłowej w Zabrzu. Budownictwo Górnicze i Tunelowe, 1: 50-62.

Bukowy S., 1974. Zapadlisko Górnośląskie. Monoklina śląsko-krakowska. Zapadlisko przedkarpackie. In: Pożaryski W. (red.), Budowa geologiczna Polski. T. 4: Tektonika. Cz. 1: Niż Polski. Wydawnictwa Geologiczne, Warszawa: 213-234.

Chmura J. \& Wójcik A.J., 2009. Adaptacja dąbrowskiej „Sztygarki” na podziemną trasę turystyczną. Górnictwo i Geoinżynieria, 33(3/1): 75-86.
Ciepiela B., 2007. Z historii górnictwa. Kopalnia węgla „Paryż” (17851991-2001). Wiadomości Górnicze, 58(3): 165-170.

Cygnarowska M., 2017. Od placówki szkolnej do muzeum. Historia dąbrowskiego muzealnictwa. Twoje Zagłębie, 14.05.2017, https:// twojezaglebie.pl/muzeum-miejskie-sztygarka-historia/.

Czornik M., Bugno-Janik A., Janik M. \& Gradoń W., 2011. Strategia Rozwoju Miasta Tarnowskie Góry do roku 2022, Tarnowskie Góry.

Drobniak A., Baron M., Czornik M. \& Gibas P. (red.), 2020. Zabrze 2030. Strategia rozwoju miasta, UM, Zabrze, UE Katowice.

Duży S. \& Preidl W., 2011. Deformacje nieciągłe na obszarze kopalni ćwiczebnej ,Sztygarka” w Dąbrowie Górniczej. Górnictwo i Geologia, 6(1): 59-73.

Dzięgiel M., 2007. Skansen górniczy „Królowa Luiza” w Zabrzu jako przykładowy obiekt geoturystyczny w środowisku przekształconym na terenie Górnośląskiego Zagłębia Węglowego. Geoturysty$k a, 4(11): 23-30$. 
Dzięgiel M., 2008. Podziemne trasy turystyczne w Tarnowskich Górach (Górny Śląsk). Geoturystyka, 4(15): 51-62.

Dzięgiel M., 2011. The "Guido" historical coal mine in Zabrze as the example of geoturism in the Upper Silesian Coal Basin. Acta Geoturistica, 2(1): 8-15.

Frużyński A., 2012. Zarys dziejów górnictwa węgla kamiennego w Polsce. Muzeum Górnictwa Węglowego, Zabrze.

Gabzdyl W., 1999. Geologia złóż. Wydawnictwo Politechniki Śląskiej, Gliwice.

Gałązka-Salamon E., 2012. Architektura parku kulturowego w Zabrzu. Stowarzyszenie na Rzecz Restauracji i Propagowania Sztolni Królowa Luiza w Zabrzu „Pro Futuro”, Zabytkowa Kopalnia Węgla Kamiennego „Guido”, Zabrze.

Glimos-Nadgórska A., 2017. Dąbrowa Górnicza jako obszar turystyki historycznej. In: Hojka Z., Nowak K. (red.), Turystyka historyczna. T. 1. Wydawnictwo Uniwersytetu Śląskiego, Katowice: 263-303.

Gola A. (red.), 2020. Sztolnia Królowa Luiza w Zabrzu - podziemna podróż w czasie. Muzeum Górnictwa Węglowego, Zabrze.

Jureczka J., Dopita M., Gałka M., Krieger W., Kwarciński J. \& Martinec P., 2005. Atlas geologiczno-złożowy polskiej i czeskiej części Górnośląskiego Zagłębia Węglowego. Państwowy Instytut Geologiczny, Warszawa.

Jurkiewicz J.G., 2002. Główna Kluczowa Sztolnia Dziedziczna - najdłuższa budowla hydrotechniczna w europejskim górnictwie węglowym. In: Materialy Szkoty Eksploatacji Podziemnej. Szczyrk, 18-22 lutego 2002. T. 2. Wydawnictwo IGSMiE PAN, Kraków: 773-781.

Jurkiewicz, J.G., Kolasa, J. \& Wiśniewski, L., 2009. Główna Kluczowa Sztolnia Dziedziczna jako zabytek techniki zaliczany do europejskiego dziedzictwa kulturowego. WUG: Bezpieczeństwo Pracy i Ochrona Środowiska w Górnictwie, 7: 52-56.

Kondracki J., 2011. Geografia regionalna Polski. Wydawnictwo Naukowe PWN, Warszawa.

Kruczek Z. \& Szromek A.R., 2011. Wykorzystanie modelu R.W. Butlera w interpretacji rozwoju atrakcji turystycznej na przykładzie kopalni soli w Wieliczce. Folia Turistica, 25(2): 275-289.

Moszny J., 2003. Rola i znaczenie sztolni odwadniających w górnictwie tarnogórskim. In: Materiały z Sympozjum poświęconego 45 lat działalności Sztolni „Czarnego Pstraga” w Tarnowskich Górach zorganizowanego przez Stowarzyszenie Miłośników Ziemi Tarnogórskiej w dniu 21 września $2002 r$. Stowarzyszenie Miłośników Ziemi Tarnogórskiej, 25-39.

Pawlak Z. \& Filak M., 2017. Tarnowskie Góry / UNESCO. Stowarzyszenie Miłośników Ziemi Tarnogórskiej, Tarnowskie Góry.

Piątek E. (red.), 2013. Kopalnia Guido w Zabrzu. Fragment górnoślaskiego górnictwa węglowego. Instytut Wyszehradzki - Pszczyna, Muzeum Górnictwa Węglowego - Zabrze.

Piernikarczyk C., 1984. Sztolnia Czarnego Pstraga w Tarnowskich Górach. Wydawnictwo Sport i Turystyka, Warszawa.

Polko A., 2018. Program rewitalizacji: Dąbrowa Górnicza 2022 (aktualizacja - 2018 r.). Załącznik Nr 1 do Uchwały Nr XLV/881/2018 Rady Miejskiej w Dąbrowie Górniczej z dnia 17 października 2018 roku, Dąbrowa Górnicza.

Sobota K., 2007. Muzeum Miejskie „Sztygarka” w Dąbrowie Górniczej. Muzealnictwo, 48: 110-122.

Szlachcic-Dudzicz D., 2006. Tarnowskie Góry - geneza i najstarsze dzieje górniczego miasta. Wydawnictwo DIG, Warszawa.
Walerjański D. (red.), 2008. Barwny świat czarnych skarbów: Zabytkowa Kopalnia , Guido”. Zabytkowa Kopalnia Węgla Kamiennego "Guido", Zabrze.

Walerjański D. \& Szczypkowska M., 2010. Guido: ślaska perła techniki $=$ Silesian pearl of technology, Wydawnictwo Attyka, Kraków.

Wilanowski S., 2016. Szczegółowa Mapa Geologiczna Polski. Arkusz Katowice (943) M 34-63 A 1:50000. Wydawnictwa Geologiczne, Warszawa.

Wilanowski S. \& Lewandowski J., 2016. Szczegółowa Mapa Geologiczna Polski 1:50000. Arkusz Bytom (910). Wydawnictwa Geologiczne, Warszawa.

Wilanowski S., Krieger W. \& Żaba M., 2009. Szczegółowa Mapa Geologiczna Polski 1:50000. Arkusz Zabrze (942). Wydawnictwa Geologiczne, Warszawa.

Wilanowski S., Krieger W. \& Żaba M., 2015. Objaśnienia do Szczegółowej Mapy Geologicznej Polski 1:50000. Arkusz Zabrze (942). Wydawnictwa Geologiczne, Warszawa.

Wójcik A.J. \& Chmura J., 2008. Kopalnia ćwiczebna w Dąbrowie Górniczej. In: Szelerewicz M., Urban J. \& Polonius A., Materiaty 42. Sympozjum Speleologicznego, Tarnowskie Góry, 24-26.10.2008r. Sekcja Speleologiczna Polskiego Towarzystwa Przyrodników im. Kopernika, Instytut Ochrony Przyrody PAN, Kraków: 25-30.

Wyciszczak S. (red.), 2008. Materiaty z konferencji popularno-naukowej: 50 lat imprezy „Dni Gwarków”, 50 lat działalności Sztolni „Czarnego Pstraga” w Tarnowskich Górach, 1957-2007 zorganizowanej przez Stowarzyszenie Miłośników Ziemi Tarnogórskiej w dniu 14 września 2007 r. Stowarzyszenie Miłośników Ziemi Tarnogórskiej, Tarnowskie Góry.

Żero E., 1968. Objaśnienia do Szczegółowej Mapy Geologicznej Polski 1:50000. Arkusz Bytom. Wydawnictwa Geologiczne, Warszawa.

Ziarkowska J., 2019. Dziedzictwo uznane - wpis na Listę UNESCO a atrakcyjność turystyczna (na przykładzie Tarnowskich Gór). Turystyka Kulturowa, 3: 53-76.

Żurek L., Paruzel K. \& Szczypkowska M., 2010. Zabrzańskie podziemia - europejską atrakcją. In: Zagożdżon P.P. \& Madziarz M. (red.), Dzieje górnictwa - element europejskiego dziedzictwa kultu$r y$. T. 3. Oficyna Wydawnicza Politechniki Wrocławskiej, Wrocław: 539-551.

www1 - https://pl.wikipedia.org/wiki/Wyżyna_Śląska [accessed: 2021.02.24].

www2 - www.dabrowa.pl/dg_muzeum-miejskie-sztygarka.htm [accessed: 2020.11.08].

www3 - www.sztolnialuiza.pl/index.php/pl/kopalnia-krolowa-luiza [accessed: 2019.09.19].

www4 - www.smzt.pl/historia/droga-do-unesco/ [accessed: 2020.12.07].

www5 - www.erih.net [accessed: 2011.06.08].

www6 - www.zabytkitechniki.pl/culturalheritage/1709 [accessed: 2016.12.25].

www7 - www.sztolnialuiza.pl/index.php/pl/slider1 [accessed: 2019.09.19].

www8 - bdl.stat.gov.pl/BDL/dane/podgrup/tablica [accessed: 2021.01.13].

www9 - www.zarabiajnaturystyce.pl/fileadmin/user_upload/Frekwencja_w_atrakcjach_turystycznych_w_latach_2016-2018.pdf [accessed: 2016.12.25]. 